\title{
The Impact of Corporate Venturing on a Firm's Competence Modes
}

\section{J. Henri Burgers, Frans A.J. Van Den Bosch and Henk W. Volberda}

\begin{tabular}{|l|l|}
\hline \multicolumn{2}{|l|}{ ERIM REPORT SERIES RESEARCH IN MANAGEMENT } \\
\hline ERIM Report Series reference number & ERS-2007-061-STR \\
\hline Publication & September 2007 \\
\hline Number of pages & 36 \\
\hline Persistent paper URL & \\
\hline Email address corresponding author & hburgers@rsm.nl \\
\hline Address & Erasmus Research Institute of Management (ERIM) \\
& RSM Erasmus University / Erasmus School of Economics \\
& Erasmus Universiteit Rotterdam \\
& P.O.Box 1738 \\
& 3000 DR Rotterdam, The Netherlands \\
& Phone: + 31104081182 \\
& Fax: + 31 10 408 9640 \\
& Email: info@erim.eur.nl \\
& Internet: www.erim.eur.nl \\
\hline
\end{tabular}

Bibliographic data and classifications of all the ERIM reports are also available on the ERIM website: www.erim.eur.nl 


\section{ERASMUS RESEARCH INSTITUTE OF MANAGEMENT}

\section{REPORT SERIES}

\section{RESEARCH IN MANAGEMENT}

\begin{tabular}{|l|l|}
\hline ABSTRACT AND KEYWORDS \\
\hline Abstract & $\begin{array}{l}\text { In this conceptual paper we investigate how corporate venturing influences an organization's } \\
\text { competences. The impact of various types of corporate ventures on the portfolio of strategic } \\
\text { options of a firm's competence modes (Sanchez, 2004a; Sanchez and Heene, 2002) will be } \\
\text { assessed by distinguishing two fundamentally different dimensions of corporate venturing, } \\
\text { technology and product (Block \& MacMillan, 1993). We argue that the level of product and factor } \\
\text { market dynamism mediates the effect of corporate venturing on a firm's competence modes. } \\
\text { Corporate ventures that significantly increase the level of product or factor market dynamics will } \\
\text { lead to an increased flexibility in all five competence modes. These ventures will have a direct } \\
\text { effect on the lower-order competence modes and an indirect, lagged effect on higher-order } \\
\text { competence modes through feedback loops. The developed framework and the propositions } \\
\text { contribute to managing the ability of a firm to change its coordination-, resource and operating } \\
\text { flexibility in order to sustain value creation. }\end{array}$ \\
\hline Free Keywords & $\begin{array}{l}\text { competence-based management, corporate venturing, product and factor market } \\
\text { dynamism, flexibility }\end{array}$ \\
\hline Availability & $\begin{array}{l}\text { The ERIM Report Series is distributed through the following platforms: } \\
\text { Academic Repository at Erasmus University (DEAR), DEAR ERIM Series Portal } \\
\text { Social Science Research Network (SSRN), SSRN ERIM Series Webpage } \\
\text { Research Papers in Economics (REPEC), REPEC ERIM Series Webpage }\end{array}$ \\
\hline Classifications & $\begin{array}{l}\text { The electronic versions of the papers in the ERIM report Series contain bibliographic metadata } \\
\text { by the following classification systems: } \\
\text { Library of Congress Classification, (LCC) LCC Webpage } \\
\text { Journal of Economic Literature, (JEL), JEL Webpage } \\
\text { ACM Computing Classification System CCS Webpage } \\
\text { Inspec Classification scheme (ICS), ICS Webpage }\end{array}$ \\
\hline
\end{tabular}




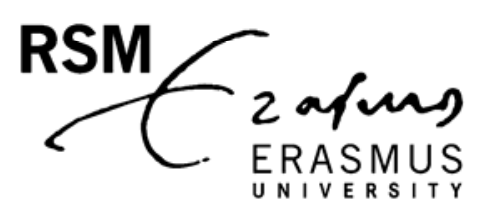

\title{
THE IMPACT OF CORPORATE VENTURING ON A FIRM'S COMPETENCE MODES*
}

\author{
Version September, 2007
}

\section{J. Henri Burgers}

\section{Frans A.J. Van Den Bosch}

\section{Henk W. Volberda}

\author{
Erasmus Strategic Renewal Center \\ Department of Strategy and Business Environment \\ RSM Erasmus University \\ P.O. Box 1738, 3000 DR Rotterdam, the Netherlands \\ E-mail: hburgers@rsm.nl \\ www.strategyaterasmus.nl
}

Forthcoming as book chapter in: Martens, R., A. Heene \& R. Sanchez (eds), Competencebuilding and leveraging in inter-organizational relations, Advances of Applied Business Strategy vol. 11, Elsevier

\footnotetext{
* The authors gratefully acknowledge the valuable comments from the editors, reviewers and from the participants of the Seventh International Conference on Competence-Based Management, June 2-4, 2005 Antwerp on a previous version of this paper.
} 


\title{
The Impact of Corporate Venturing on a Firm's Competence Modes
}

\begin{abstract}
In this conceptual paper we investigate how corporate venturing influences an organization's competences. The impact of various types of corporate ventures on the portfolio of strategic options of a firm's competence modes (Sanchez, 2004a; Sanchez and Heene, 2002) will be assessed by distinguishing two fundamentally different dimensions of corporate venturing, technology and product (Block \& MacMillan, 1993). We argue that the level of product and factor market dynamism mediates the effect of corporate venturing on a firm's competence modes. Corporate ventures that significantly increase the level of product or factor market dynamics will lead to an increased flexibility in all five competence modes. These ventures will have a direct effect on the lower-order competence modes and an indirect, lagged effect on higher-order competence modes through feedback loops. The developed framework and the propositions contribute to managing the ability of a firm to change its coordination-, resourceand operating flexibility in order to sustain value creation.
\end{abstract}

Keywords: competence-based management; corporate venturing; product and factor market dynamism; flexibility 


\section{Introduction}

The competence perspective has evolved into a major line of thinking in contemporary management literature. While there is a vast body of knowledge about what competences are and how they should be managed there is still insufficient understanding of how competences are developed. Small project teams within existing units are likely to enhance the existing base of competences. To develop new competences for the company, the development should take place in units that are managed separately from the existing units (Benner and Tushman, 2003; Hill and Rothaermel, 2003; McGrath, 2001). Corporate venturing is a tool to autonomously explore new competences within the boundaries of the parent firm (Block and MacMillan, 1993; Guth and Ginsberg, 1990; Zahra et al., 1999). These newly developed competences have to be reintegrated in the existing competence base of the organization, leading to processes of strategic renewal (Guth and Ginsberg, 1990; Volberda et al., 2001).

In this paper we adopt a competence perspective to investigate these renewal processes, and in particular the effect of corporate venturing on firms' competence modes. The performance of firms improves if their competence modes are aligned with the level of environmental dynamism (Sanchez, 2004a). Furthermore, the impact of corporate venturing on an organization is contingent on the competitive environment (Stopford and Baden-Fuller, 1994; Zahra, 1993). Corporate ventures can trigger an increase in market dynamism, to which the firm has to react by adapting its competence modes.

The purpose of this paper is, therefore, to investigate the impact of corporate venturing on firm's competence modes, taking into account the mediating role of market dynamism. The paper proceeds as follows. First, we will introduce our three building blocks of the framework: corporate venturing, competence modes and the competitive environment. Second, we will develop a conceptual framework and propositions by distinguishing two effects of corporate 
venturing on a firm's competence modes: ventures fitting within the existing level of market dynamism and competence modes, and ventures enlarging the flexibility of the competence modes through an increase in market dynamism. We will conclude with a discussion of the implications and point out issues for future research.

\section{Corporate venturing}

Researchers have long since argued that creating new businesses versus managing existing businesses are two fundamentally different processes (Duncan, 1976; Gibson and Birkinshaw, 2004; March, 1991). Around 1980 a number of authors argued that corporate venturing contributes to solving this tension between exploitation and exploration. Initially the domain of corporate ventures was restricted to New Venture Divisions, which were managed separate from all other businesses and reported directly to the board of management of the company (Burgelman, 1983b; Fast, 1979). The underlying assumption regarding corporate venturing and innovation in general is that the less related the venture is to the parent firm's competence base, the more autonomy the venture needs (Burgelman, 1984; McGrath, 2001; Sorrentino and Williams, 1995; Thornhill and Amit, 2001). From that perspective, a new venture division was seen as a tool to develop businesses lying outside the company's base of competencies. Later authors broadened the definition of corporate venturing by including ventures in other parts of the organization that are closer related to the parent's competence base in their definition (Block and MacMillan, 1993; Burgelman and Valikangas, 2005; Husted and Vintergaard, 2004; Sharma and Chrisman, 1999).

We adhere to these later insights and define corporate venturing as the creation of new businesses within an existing organization aimed at the development of new competences. Corporations can start venture programs for a variety of reasons, but a predominant one is that 
successful venturing can rejuvenate the mature business (Burgelman, 1983a; Sharma and Chrisman, 1999; Zahra, 1996). Corporate ventures achieve this by creating or enhancing competences for the parent firm (Guth and Ginsberg, 1990; Zahra et al., 1999). To what extent the venture develops competences new to the organization can be measured by a concept called relatedness (Burgelman, 1984; Sorrentino and Williams, 1995). Block and MacMillan (1993) distinguished three dimensions of relatedness of a corporate venture: product, technology, and market. Together these three dimensions determine the novelty of a corporate venture relative to the parent firm.

\section{Three dimensions of a corporate venture}

The product dimension measures the novelty of the products a venture develops compared to the current offerings of the parent firm. Ventures developing new products can either complement or substitute a product in one of the firm's existing markets (Methe et al., 1997). Ventures adding a new product strengthen the firm’s market position through broadening the product range by launching complementary products. Microsoft's launch of MS-Office and Internet Explorer, for example, was aimed at broadening the product range and strengthening the dominance of Windows 95 and Windows 98 respectively. Ventures aimed at replacing an existing product strengthen the firm's position by raising the value of the offered product. Microsoft, for example, relentlessly introduced new versions of Windows even while Microsoft obtained a market share of 90 percent for Windows in 1992 (Rebello, 1992).

The technology dimension refers to the extent to which the venture develops new technological competences relative to the parent firm. This type of venture is associated with competence destroying innovations, as it makes the existing technology obsolete. When Pilkington invented the float glass process in the 1950s, it made the existing grinding process 
obsolete as "a float line would ultimately more than halve labor requirements; it would lower energy costs by about 50 percent; the $15-25$ percent of glass ground away in earlier processes would be saved; ...equipment investment would be about one-third... production space requirements would drop by over 50 percent; and process interruption costs would virtually disappear" (Quinn, 1989: 862). However, the product itself did not change, as "it would not be sufficiently better than existing plate to demand a premium price because of its quality” (Quinn, 1989: 862).

The market dimension refers to whether the venture aims at new markets. Competences regarding new markets refer to the ability of opening up new distribution channels, trying out new marketing approaches with different sets of customers or geographically different markets. The venture developing a new market could trigger an integration of this new market with the firm's current markets or it could be used to leverage the company's current technological or product competences in new markets. In the remainder of this paper we will limit ourselves to the product and technology dimension of a venture.

\section{Competence-based management and competence modes}

There is a long-standing tradition in management literature to view the firm as a bundle of resources (Barney, 1991; Dierickx and Cool, 1989; Penrose, 1959; Wernerfelt, 1984). Even the earliest notions of entrepreneurship refer to this point-of-view, as entrepreneurship is about the creation of new bundles of resources (Kirzner, 1973; Schumpeter, 1934). Barney (1991) argued that among others, resources must be unique and imitable to achieve sustainable competitive advantage. This led many researchers to question whether the traditional more physical resources could lead to competitive advantage, as many firms could possess them. Thus the resource-based view of the firm was extended with the concept of dynamic capabilities and 
competences. Dynamic capabilities are the routines by which firms reconfigure resource combinations (Eisenhardt and Martin, 2000; Jansen et al., 2005; Teece et al., 1997). Although of a higher-order and more tacit than resources, dynamic capabilities in essence still depend on resources. Their competitive advantage results from the resource configurations and not from dynamic capabilities per se (Eisenhardt and Martin, 2000). Prahalad and Hamel (1990) developed the concept of core competences, which span units and businesses and are the collective learning in an organization, in particular the coordination of production skills and the integration of multiple streams of technology (Prahalad and Hamel, 1990; Rumelt, 1994). Originally the concept of core competences referred to more technical competences, like Honda’s world-class ability to build small engines or Sony's competence in miniaturization. Later work has developed this notion into "higher-order" competences, including the ability to define alternative strategic logics and a direct link with organizational and strategic flexibility (Hamel and Heene, 1994; Sanchez, 2001; 2004a; Sanchez et al., 1996).

Competence-based management focuses on conceptualizing and analyzing the competences of organizations including how competences may help organizations to adapt to changing environments. This perspective views organizations not only by their resource base, but also by their strategic goals, strategic logics and by the different ways in which organizations coordinate deployments of resources (Sanchez et al., 1996). Competence-based management has contributed to our understanding of firms as open systems which pursue strategic goals according to a strategic logic. This logic, in turn, shapes the management processes that determine how a firm acquires and uses resources; being within a firm's boundaries (firm-specific resources) or outside its boundaries (firm-addressable resources) (Sanchez and Heene, 1997). 
Five modes of competence

Sanchez and Heene (1997) proposed a model of the firm as an open system consisting of various layers: strategic logic, management processes, intangible and tangible assets, operations and finally product offerings. Sanchez and Heene (2002) and Sanchez (2004a) extended this model by proposing five competence modes, each mode addressing different sources of flexibility creating different portfolios of strategic options. A competence mode "results from a distinctive kind of organizational flexibility to respond to changing and diverse environmental conditions" (Sanchez, 2004a: 523). Figure 1 shows the five competence modes and their respective flexibility. Each competence mode is related to a distinct aspect of the organization, with the highest mode of strategic logic on the left to the resources on the right. The level of flexibility (Volberda, 1998) refers to the ability to define alternatives for the existing resources or to the ability to put the existing resources to different uses. In other words, the higher the level of flexibility the broader the range of strategic options and corporate ventures a firm is able to develop.

The first competence mode operates at the highest level of strategic logics (see Figure 1). The cognitive flexibility of top and senior managers to define alternative strategic logics creates a portfolio of strategic logics. The broader and more varied this portfolio, the better top- and senior management is able to perceive opportunities to create value.

The second competence mode relates to management processes and the cognitive flexibility of top- and senior management to define alternative management processes to create value (see Figure 1). It is of a lower level in the sense that this competence mode refers to the flexibility in creating different management processes for a single strategic logic. Through feedback loops management processes could also trigger the definition of new strategic logics. 
Insert Figure 1 about here

The management processes-in-use determine to some extent the ability of the company to manage resource chains. The third competence mode refers to the coordination flexibility to identify, configure and deploy chains of resources. This competence mode taps most directly into the original thinking in the fields of entrepreneurship and dynamic capabilities (cf. Schumpeter, 1934; Teece et al., 1997). Through feedback loops, new configurations of resources can also lead to the definition of alternative strategic logics.

The inherent flexibility of resource chains to be used in alternative operations is the fourth competence mode. The flexibility of this resource can be defined according to the range of possible uses for the resources, including the time it takes and the costs it incurs to change the use of a particular resource (Sanchez, 2004a). This flexibility of a resource to be deployed in alternative ways could also create new opportunities to configure new resource chains.

The fifth and final competence mode focuses on operating flexibility in applying skills and capabilities in the use of available resources (see Figure 1). This flexibility relates in particular to the design of operating processes, like moving the order point downstream through use of modular product architectures (Sanchez and Mahoney, 1996). Mastering the skills of operating flexibility could in turn lead to higher flexibility in "higher-order" competence modes, as these skills might be applied in alternative resource chains, management processes or even strategic logics. 
When portraying the competence modes as some kind of "flexibility funnel" through which ideas have to flow (see Figure 1), the broader the portfolio of strategic options created by each competence mode, the more flexible and adaptive the firm will be. To avoid bottlenecks in the flexibility funnel the coherence of the portfolio and the complementarities of the five competence modes need to be managed (Sanchez, 2004a). Bottlenecks limit the overall competence of an organization, and have an impact on the other competence modes "because each of an organization's competence modes will tend to equilibrate with the least flexible competence mode of the organization” (Sanchez, 2004a: 528). This suggests relating the type of competitive environment with the competence modes that may operate as the most limiting factor regarding flexibility. For example, in a stable environment it makes no sense to have substantial cognitive flexibility of top and senior managers. In dynamic environments, characterized by frequent and uncertain changes in market preferences and available technologies, however, the cognitive flexibility to define alternative strategic logics and management processes, i.e. the first and second competence mode, are the most critical.

\section{Competitive environment}

The firm's competitive environment, and in particular environmental dynamism, is a frequently addressed factor in corporate entrepreneurship research (e.g. Lumpkin and Dess, 2001; Zahra, 1996). Researchers have focused on both the objective and the perceived environment. The enacted environment is the basis for managerial action (Penrose, 1959; Weick, 1979). Zahra (1993) found that the perceived level of environmental dynamism significantly and positively influence the venturing activities a firm undertakes. Whereas the perceived environment leads to managerial action, the objective environment determines the

quality of the opportunity for the venture (Tsai et al., 1991). In other words, all managerial 
action will ultimately be put to the test in the market place. Our focus is therefore on the objective environment.

Four generic types of environment

Sanchez (2004a) distinguished three types of environment by differentiating between the amount of change in market preferences and technologies. We propose to extend this model by suggesting that the level of change in technologies and market preferences do not necessarily have to be the same. Following Floyd and Lane (2000) we make a distinction between product and factor market dynamism. We focus on dynamism as it captures the frequency and intensity of change in a firm's industry (Volberda, 1998). Product market dynamism refers to positioning strategies, market preferences and competence-enhancing behavior, while factor market dynamism refers to changes in technologies and competence-defining behavior (Floyd and Lane, 2000). Figure 2 combines product and factor market dynamism to create a $2 \times 2$ matrix of four generic types of environment: stable competition, product-driven competition, technologydriven competition and hypercompetition.

Insert Figure 2 about here

Stable competition is characterized by both stable product and stable factor market conditions. The frequency and intensity of changes are low, allowing firms to remain passive with respect to their environment and focus on short-term efficiency instead of flexibility. The focus will be on competence mode V (Sanchez, 2004a). Under the conditions of stable 
competition, managers who tend to follow the industry rules will not initiate corporate ventures that focus on their existing markets. These ventures would disturb the market's equilibrium by increasing the level of dynamics, which would be in conflict with the focus on stability. Firms encountering stable competition, focus on entry barriers to restrain the rivalry within the industry (D’Aveni, 1999), providing incumbent firms with a steady cash flow without having to incur high $\mathrm{R} \& \mathrm{D}$ costs.

A high level of dynamism on product markets and a stable factor market characterizes product-driven competition (see Figure 2). With this type of competitive dynamics the underlying technologies remain relatively unchanged, which allows firms to enhance their current set of core competences by constantly improving the product range of the company (D’Aveni, 1999) or engage in customer segmentation (Floyd and Lane, 2000). D’Aveni (1999: 131) argued that incumbent leaders in a competence-enhancing environment "sustain their leadership by layering new competences on top of old ones”. In this type of environment the emphasis will be on competence mode IV, as resources need to be applied and leveraged in different products.

Technology-driven competition with the associated technological discontinuities and patterns of punctuated equilibria has been extensively documented in the literature (e.g. Anderson and Tushman, 1990; Tripsas, 1997; Tushman and Anderson, 1986). These companies face dynamic factor markets but relatively stable product markets. Firms will focus defining new competences (Floyd and Lane, 2000). The emphasis will be on competence mode III, as firms develop new resource chains to cope with the dynamics on its factor market.

Hypercompetition is characterized by inherent instability and change (D’Aveni, 1994). Firms try to gain a series of short-lived advantages by actively destroying their own competences (D'Aveni, 1994; 1999; Floyd and Lane, 2000). Organizations in these contexts 
need speed-based processes and greater flexibility (Volberda, 1998) to handle the combination of dynamic factor and product markets. Firms facing hypercompetition need to continuously create new competences and disrupt the environment before rivals do (D’Aveni, 1999). Firms focus on competence modes I and II, as having a broad portfolio of strategic logics and management processes is critical in coping with a variety of situations in a hypercompetitive environment.

\section{Conceptual framework and propositions}

Corporate ventures develop new businesses and present new strategic options to the firm. By doing so, corporate ventures might need new management processes, new strategic logics or new combinations of resources. If the needs of the corporate venture are beyond the flexibility of the competence mode, the level of flexibility in the respective competence mode needs to be increased. Burgelman (1983a) argued that ventures will first need to build a strategic context before changes will take place on a broader scale in the firm. We argue that the need to increase flexibility in competence modes is not triggered by the corporate venture directly, but that the level of product and factor market dynamism mediates the impact of various types of corporate ventures on the flexibility of a firm's competence modes. ${ }^{1}$

Corporate venturing and the competitive environment have frequently been linked to each other (Tsai et al., 1991; Zahra, 1993). Miller and Friesen (1982: 6), for example, pointed out that: "because innovation prompts imitation, the more innovative the firms, the more dynamic and competitive (hostile) their environments can become.” In other words, innovative corporate ventures can have a significant impact on the competitive environment of the parent

\footnotetext{
${ }^{1}$ We would like to thank an anonymous reviewer for his help in clarifying the relationships between our constructs.
} 
firm. Management needs to align the firm in response to changes in their competitive environment (Burgelman, 1991; Burns and Stalker, 1961; Floyd and Lane, 2000; Huff et al., 1992; Naman and Slevin, 1993). Volberda and Lewin (2003) argued that self-renewing organizations should at least match the internal rate of change to the rate of change of their environment. In other words, the level of flexibility in competence modes needs to be adjusted in response to changes in a firm's competitive environment. If the corporate venture does not have a major impact on the environment, the competence modes of the firm are already adapted to handle this new venture.

In developing our conceptual framework, we discern two possible effects of corporate venturing on the level of environmental dynamism and modes of competence. The first effect of a corporate venture is maintaining fit with the parent firm's competitive environment. We define fit as the degree to which firms in that particular industry are used to dealing with the changes resulting from the corporate venture. Firms in the consumer electronics industry are, for example, used to dealing with the emergence of new standards like the VHS, CD, or DVD, just as firms in the fashion apparel industry are accustomed to frequently modifying their product lines according to the latest trends. From an alignment perspective the parent firm will be capable of handling these changes, and the relatively small deviation from the existing situation does not call for increased flexibility in the competence modes of the organization. The firm will stay inside its box of competitive dynamics (see Figure 2).

The second effect of a corporate venture is changing the rules of the industry giving rise to a significant increase in the level of competitive dynamism in the parent firm's industry. In that case there is a misfit with the competitive environment, as firms are not used to dealing with these kinds of changes. For example, banking, and specifically stock trading, has significantly changed since the emergence of the Internet. Many banks had serious difficulty in adapting to 
the new situation, as the banking industry had been stable for decades. These ventures will initiate a transition from one box of competitive dynamics to another. This requires, however, increasing the flexibility of the competence modes to realign the firm with its competitive environment.

Ventures fitting within the competitive environment and the existing flexibility of the competence modes

The alignment perspective has gained widespread ground in management literature (Floyd and Lane, 2000; Naman and Slevin, 1993). Sanchez (2004a) suggested that the level of flexibility in each competence mode should fit with the environment. Over time, excess flexibility will decrease until all modes are in balance (see Figure 1). Burgelman (1991) suggested that internal selection processes regarding corporate venturing could only be effective in the long run when they resemble environmental selection pressures. In other words, the competence modes of the parent firm will be able to handle corporate ventures that do not increase the level of product and factor market dynamism. The venture develops new product or technological competences which the firm has to incorporate in its strategy. However, these adjustments of the technological and product base of the company can be handled by the existing flexibility of the firm's competence modes. The corporate ventures that fit with the competitive environment should not face bottlenecks when moving through the competence modes (see Figure 1).

Product market dynamism refers to new product introductions and positioning strategies, and is associated with competence enhancing behavior (Floyd and Lane, 2000). Dynamic product markets are characterized by a low intensity, but high frequency of change. Firms are 
able to adapt to this strategic need for frequently launching new products and modifications through product development ventures, as the technological base of existing product lines remains intact. From an alignment perspective, ventures developing new products will fit with dynamic product markets. Zahra (1993) empirically verified that managers who perceived a great demand for new products (i.e. dynamic product markets) strongly preferred new product innovation. Firms operating in dynamic product markets therefore do not have to change their competence modes when developing a product development venture.

Technology development ventures fit with dynamic factor markets. Factor market dynamism is associated with changes in technologies and processes, and with competence destroying behavior (Floyd and Lane, 2000). It is characterized by a low frequency but high intensity of change. Anderson and Tushman (1990) suggested that radical technological changes lead to a short period of ferment, characterized by rapid competence destroying turbulence, followed by a longer period of relative stability. Environments with abundant technological opportunities (i.e. high factor market dynamism) are positively associated with technological entrepreneurship (Zahra, 1993). Corporate ventures developing new technologies will not lead to changes in the flexibility of the competence modes if the firm has its competence modes already geared towards dynamic factor markets.

Ventures increasing the required flexibility of the competence modes

In the previous paragraph we argued how certain types of ventures can achieve fit with competitive environments. But what if these ventures are initiated in a stable product or factor market and change the competitive dynamics of a firm's industry? Ventures deliver new value propositions for a market, but they can also challenge the way firms compete with each other. 
Competitors are likely to follow a product introduction or counter-attack with an even better product or technology, resulting in an increase of market dynamism (D’Aveni, 1999; Miller and Friesen, 1982). These rule-changing ventures push the firm to another "box" of competitive dynamics (see Figure 2) forcing the firm to enlarge the flexibility of its competence modes. This significant increase in competitive dynamics cannot be handled within the systems-in-use. Changes in competence modes will be necessary, ranging from new managerial cognitions to operational processes (Barr et al., 1992; Forte et al., 2000; Sanchez, 2004a; Stopford and BadenFuller, 1994).

In a stable market, a firm would most likely have a narrow and balanced "flexibility funnel” (see Figure 1). However, when such a firm is confronted with a dynamic market, the flexibility mix of the firm will be too narrow. Being able to deal with dynamic markets requires new management processes and cognitive logics to increase the portfolio of strategic options. Sanchez (2004a) argued that over time the system is likely to equilibrate, as excess flexibility in one of the competence modes is likely to diminish towards the flexibility level of the bottleneck. In other words, a transition from a stable to a dynamic market triggers changes in the level of flexibility in all five competence modes.

Ideally these changes should be managed simultaneously, but in reality changes will be made more sequentially. Changes in the flexibility of the competence modes are subject to increasing dynamic response times, and the pace of change will therefore be set by the inertia associated with the managerial cognitions in the highest competence modes (Tripsas and Gavetti, 2000; Sanchez, 2004a). The realignment process will only be complete when all five competence modes have changed, but corporate ventures can temporarily escape the selective effects of the current cognitive context of competence modes I and II (Burgelman, 1983a). Over time such a corporate venture will trigger changes in the strategic and structural context, when 
top management retroactively rationalizes the venture and approves the changes in the competence modes (Burgelman, 1983b). The venture has by that time already become part of the lower levels of the organization. Top management may approve the changes in higher-order competence modes such as alternative strategic logics or changes in management processes, but the venture will have ignited changes in the more downstream competence modes of operational flexibility and reconfiguration of resource chains. Below we will outline the order in which the level of flexibility of the competence modes increases, based on changes in product and factor market dynamism respectively (Floyd and Lane, 2000; Sanchez, 2004a).

\section{$\underline{\text { Product development ventures increasing product market dynamism }}$}

An innovative product development venture could change a stable into a dynamic product market, due to imitation behavior of competitors. Dynamic product markets are characterized by a high frequency of change, but the intensity of the individual changes is relatively low. With this type of competitive dynamics the underlying technologies remain more or less the same. This allows firms to enhance their current set of core competences by constantly improving the product range of the company (D’Aveni, 1999), or engaging in customer segmentation (Floyd and Lane, 2000). Sanchez (2004a: 526) suggested that "in an environment in which market preferences are evolving rapidly, the flexibility to redeploy an existing resource chain from one product offer to a new or modified product offer will be of paramount importance in sustaining value creation.”

Insert Figure 3 about here 
We suggest that a corporate venture developing new products and triggering a change towards a dynamic product market will first influence competence mode IV (see Figure 3). The resource chains will stay the same, but will be put to different use in new products. Due to the increased flexibility in competence mode IV created by the product development venture and the resulting increase in product market dynamism, there will be a temporary imbalance in the competence funnel with bottlenecks arising in competence modes I-III and V. The increased flexibility in competence mode IV will put direct pressure on competence mode V to enlarge its operating flexibility to put the new resources to use, as the product development venture facilitated by the flexibility in competence mode IV should not be constrained by mode V. The shorter response time for competence mode V relative to IV (Sanchez, 2004a) should solve this problem. However, as the firm now has to cope with a dynamic product market, it will also need new management processes and strategic logics. These adaptations will take more time and will only retroactively be initiated. These lagged effects are represented by the dotted arrows in Figure 3.

Proposition 1: In the context of a stable product market, a successful venture that develops new products will significantly increase the level of product market dynamism and is likely to raise the level of flexibility of all five competence modes, through a direct effect on competence modes $I V$ and $V$ and an indirect, lagged effect on competence modes I-III.

Technology development ventures increasing factor market dynamism 
A second possible transition is from a stable to a dynamic factor market. Ventures that develop new technologies can trigger competitive reactions and initiate a shift to a dynamic factor market. The effects of technological discontinuities have been extensively documented in the literature, but mostly from an industry perspective (e.g. Adner, 2002; Anderson and Tushman, 1990; Arend, 1999; Christensen, 1997). However, such a discontinuity and shift from a stable to a dynamic factor market also has consequences for the firm and the flexibility of its competence modes. New technologies have implications for an organization's value chain, as firms might need new suppliers, ways of producing, and the like. Volberda et al. (2001) suggested that these technological changes, which are deeply rooted in the organization, require transformational renewal (Volberda et al., 2001). Sanchez (2004a: 526) argued that in environments in which "technologies are changing, the flexibility to define and assemble new resource chains based on newly available technological resources or to integrate new technologies into existing resource chains will be critical.”

Venture developing new technologies in a firm operating in a stable factor market will therefore first trigger a need for more coordination flexibility (see Figure 4). The need to introduce the products developed by the venture on the market will trigger an increase in flexibility in competence modes IV and V. Again, because ventures are autonomous initiatives that have escaped the selective effects of the cognitive mindsets of the firm, the effect on competence modes I and II will be lagged (see Figure 4). In the long-term an increase in cognitive flexibility will be necessary to remove the bottlenecks that will occur due to the technological development. Moreover, operating in a technologically challenging environment will demand new management processes and strategic logics to ensure firm survival. An ability to quickly react when facing a technological discontinuity has been deemed paramount for 
continuing firm survival (D’Aveni, 1999; Volberda et al., 2001), suggesting the following proposition.

Proposition 2: In the context of a stable factor market, a successful technology development venture will significantly increase the level of factor market dynamism and is likely to increase the level of flexibility of all five competence modes, through a direct effect on competence modes III-V and an indirect, lagged effect on competence modes I and II.

Insert Figure 4 about here

Increasing flexibility in all competence modes: the case of Philips' electronic toothbrush product development venture

We will illustrate how a product development venture increases the flexibility in all competence modes with the example of the efforts of Philips entering the electronic toothbrush market. During the early 1990s the Domestic Appliances and Personal Care (DAP) division within Philips was active in several markets that were rapidly maturing, like shaving products, vacuum cleaners, and coffee makers. The exploitation-driven activities made DAP one of the most profitable businesses within Philips, but during the early 1990s it appeared that growth in these markets was nearing its end. A major opportunity for additional growth took the form of the electronic toothbrush market. Braun launched a revolutionary electronic toothbrush in 1991, 
which spurred growth rates to double-digit figures, with peaks of around 30\% market growth in the mid 1990s. As a result, DAP started to develop these toothbrushes internally ${ }^{2}$.

Oral healthcare started as an autonomous venture team in Japan and was transferred to Klagenfurt, DAP’s competence center for personal care products, after a year. The electronic toothbrush business unit still has considerable autonomy, as it is the only DAP business that is managed from Seattle instead of the Netherlands. For a division that aimed at exploiting its existing businesses for over a decade, the development of a new business in a market that experienced faster growth rates and frequent establishment of new standards required increasing the flexibility in all five competence modes. Although the resource chains in terms of R\&D were largely in place, the flexibility of competence mode IV had to be increased, as resources had now to be applied in new operations. Operations were new in two ways: 1) it was a new product category for DAP, and 2) it was new business development opposed to the product development DAP usually carried out. In 1994 the first products appeared (Philips Annual Report 1994), which indicates DAP had succeeded in increasing the resource flexibility of competence mode IV. This put pressure on competence mode $\mathrm{V}$ to increase its flexibility to reliably and efficiently produce the electronic toothbrushes. The first products that appeared on the market had serious quality problems and high field call rates. The venture team found out that it lacked the skills to test the product on durability, which pressured DAP into increasing its flexibility in mode $\mathrm{V}$ by developing new testing skills.

\footnotetext{
${ }^{2}$ For publicly available background on Philips' efforts in the Dental Care market, we refer to several case studies from IMD by Sanchez (2003a; 2003b; 2003c) and Schweinsberg and Hum (2000a; 2000b). See also Sanchez (2004b).
} 
Once the products were on the market, the pressure on competence modes I-III was building to increase flexibility, as the cognitive flexibility, management processes and resource chains were not suited for the oral healthcare market for a number of reasons. First, the market had a strong medical aspect in it, as success was dependent on professional endorsement by dentists and clinical trials. Second, in particular in the early 1990s the leading market for electronic toothbrushes was the US, which had traditionally been a difficult market for DAP. Third, Braun had become the market shaper, in which it could set the pace of innovation and the product standard. This required a new strategic logic of DAP, where the sales force had to move away from traditional electronic retailers to professional dentists. DAP had to rethink its communication strategy, as the buying process for medically-oriented products is more complex and longer than for traditional products of DAP. If consumers buy a coffeemaker, for example, they go to the store and buy one. For an electronic toothbrush, consumers would ask their dentist, their family and friends, read about it etc. before they decide to buy one. The managerial cognition of DAP's management was aimed at achieving quick results from the position of a market shaper as in the shaving products sector. Yet in oral healthcare DAP was a challenger and the cognitive flexibility had to change to either becoming a market shaper in the long-term or achieve quick results through undercutting Braun's prices. The strategy of the oral healthcare venture switched back and forth between both strategies during the 1990s, as it proved very difficult to change the dominant strategic logic.

To solve these issues DAP partnered with Jordan in 1997, which had the brand credibility and a network of dentists. Jordan would manufacture the brush heads and DAP would concentrate on the body of the electronic toothbrush. The alliance not only required a further increase in cognitive flexibility, as DAP did not use alliances before, it also required an increase in coordination flexibility to switch from firm-specific resources to firm-addressable 
resources. The alliance became an immediate success, with Philips capturing significant market share in Europe. Soon after that, the problems started, as the in-company focus of both parties led to distrust of each other. Management processes and the cognitions of both companies did not provide flexibility to deal with alliances. The alliance with Jordan was discontinued in 1999 and DAP refocused on in-house development again.

At the same time there was increasing price pressure from Braun, which triggered the increase of the operating flexibility of competence mode V. It needed to both raise quality and reduce the cost price and Philips moved the order-decoupling point in its supply chain downstream through a modular architecture of the electronic toothbrush (Sanchez, 2004b). Quality standards were indeed markedly improved and cost price significantly reduced. At that point the lower competence modes (IV and V) had a sufficient level of flexibility to successfully develop a business in electronic toothbrushes. DAP's management also recognized that it needed a position in the US and a superior product to Braun. One problem that remained was that DAP still did not have the capabilities to build professional endorsement and it lacked the time to develop a superior product. The lessons learned from its endeavors in the oral healthcare market (almost 10 years) had raised the coordination flexibility to such an extent that it became possible to look for external parties. A start-up (Optiva) had successfully challenged Braun's market leadership in the US by producing a toothbrush with superior cleaning capabilities and the decision was made to acquire Optiva in October 2000 (Philips Annual Report 2000). In 2001 the oral healthcare business started to contribute to DAP's profitability (Philips Annual Report, 2001), after almost 10 years of struggling. The former business manager of oral healthcare suggested that they would never have been able to successfully acquire Optiva, without first having learned what it takes to compete in the oral healthcare market. This example illustrates the effects a venture can have on all competence modes, and indicates the importance of 
envisioning the changes needed in all five competence modes, instead of focusing on one or several competence modes.

\section{Discussion}

In this conceptual paper we sought to identify how corporate venturing influences an organization's competences. The level of product and factor market dynamism mediates the impact of various types of corporate ventures on the flexibility of a firm's competence modes. Two effects were pointed out: ventures that achieve fit with the environment and the firm's competence modes and ventures that significantly increase the level of market dynamism and the amount of flexibility in all five competence modes. The developed framework enhances our understanding of the competence-based view by addressing the effect of corporate ventures and the competitive environment on the five competence modes developed by Sanchez (2004a).

With our focus on corporate ventures that triggered changes in the level of industry dynamics and the firm's competence modes, we have limited ourselves to firms initiating change in an industry. An interesting question would be how changes unfold in a firm that is a follower. We suggest the end result regarding the level of flexibility in all five competence modes will be the same for initiators and followers in the same industry, as the level of flexibility in the competence modes is contingent on the level of dynamism in a firm's industry. We expect the pattern of change to differ significantly for followers and initiators. Changes in the level of flexibility of competence modes in an initiator will be endogenously driven by a corporate venture and will start in competence mode III or IV (see Figures 3 and 4). For a follower-firm the changes will be exogenously driven by changes in the competitive environment. Further research is needed on these follower firms and their process of changing 
the flexibility in the competence modes, but we suggest change starts in competence mode $\mathrm{V}$, which is closest to the marketplace. Several implications result from this paper.

First, it is important to realize that the changes in competence modes should be managed from an integrative perspective, as a change in one competence mode will eventually trigger changes in all other competence modes. Although these effects might be lagged, they have to be managed to re-align the firm with its competitive environment. Furthermore, increases in the flexibility of competence modes might also lead to the identification of additional opportunities for the firm, which were initially not realized within the existing strategic logic of the firm.

A second implication is that corporate ventures should be carefully managed. Researchers have criticized corporate venturing for only developing peripheral activities and its cyclical behavior (Burgelman and Välikangas, 2005; Campbell et al., 2003). We argue that corporate ventures can deliver substantial growth opportunities for the firm, if the firm manages these ventures and its effects on firm's competence modes. It is, however, often difficult to manage these ventures, as the nature of their activities requires a more arm's length approach. However, failure to grasp the possible consequences of a venture for the firm and its environment often places the firm in a much more precarious situation of a new entrant commercializing the ideas originally invented in the parent firm, which could ultimately lead to failure of the incumbent firm (Christensen, 1997).

Third our framework helps managers in assessing ex ante the consequences of a corporate venture. Previous research on disruptive technologies has been criticized for only being able to analyze post-hoc the disruptiveness of a technology (Danneels, 2004; Govindarajan and Kopalle, 2006). Our conceptual framework serves as a first step in making a priori predictions on the consequences of a corporate venture. To function as such a tool, however, at least two other questions should be solved by further research. First, we need more 
research regarding the issue when a corporate venture leads to significant changes in the competitive environment and the firm's competence modes. Is there a specific level of dynamism that separates stable from dynamic markets, or is there a grey area in which the effect of ventures on dynamism and the firm's competence modes varies from industry to industry. Secondly, if managers want to be capable of making ex ante predictions, their perceptions of the level of dynamism should match with the actual level of dynamism, but this is not necessarily the case (Tosi et al., 1973). To facilitate progress in this field of research, it is important to develop objective, quantitative metrics that measure the level of dynamism of the competitive environment and the newness of a corporate venture.

Another issue inviting further research is the process dimension of venturing. Ventures undergo several stages from idea development to roll-out, and it is worthwhile investigating how the effects the venture has on the product and factor markets and subsequently on the competence modes differ during each phase of the venture's life cycle. Changes in competence modes might take considerable time, and hence it is beneficial if firms are aware of these effects as early as possible in the venture life-cycle.

Besides the technology and product dimension of corporate ventures addressed in this paper, the market dimension could also be incorporated into our framework. Corporate ventures focusing on new markets will have an influence on a firm's competences, but it is unclear on which competence modes these ventures have an effect. Markets that lie far outside of what the firm is currently doing could have an effect on the cognitive flexibility of top management, as they would need to define alternative strategic logics for this new market and venture. On the other hand, the marketplace is situated downstream in Sanchez's (2004a) competence modes framework and might have less of an effect on competence modes than the product and technology dimension of a venture. We call upon researchers to develop a more thorough 
understanding of this relationship through empirical testing. Developing appropriate methodologies and metrics will, however, be a major challenge for future researchers.

Concluding, we believe investigating the under-researched area of the interplay between corporate venturing and competence modes will benefit from our framework and propositions. These efforts will put corporate ventures high on the strategic agenda of top management, as aligning corporate venturing with the firm's competence modes, taking into account the mediating effect of environmental dynamics, will be a key issue for sustainable value creation.

\section{References}

Adner, R. 2002. When are technologies disruptive? A demand-based view of the emergence of competition. Strategic Management Journal 23: 667-688.

Anderson, P., Tushman, M.L. 1990. Technological discontinuities and dominant designs: a cyclical model of technological change. Administrative Science Quarterly 35: 604-633.

Arend, R.J. 1999. Emergence of entrepreneurs following exogenous technological change. Strategic Management Journal 20, 31-47.

Barney, J. B., (1991), 'Firm resources and sustained competitive advantage', Journal of Management 17(1), 99-120.

Barr, P.S., Stimpert, J.L. and Huff, A.S. 1992. Cognitive change, strategic action, and organizational renewal. Strategic Management Journal 13, 15-36.

Benner, M.J., Tushman, M.L. 2003. Exploitation, exploration, and process management: the productivity dilemma revisited. Academy of Management Review 28(2), 238-256.

Block, Z., MacMillan, I.C. 1993. Corporate Venturing. Boston: Harvard Business School Press.

Burgelman, R.A. 1983a. A model of the interaction of strategic behavior, corporate context and the concept of strategy. Academy of Management Review 8: 61-70.

Burgelman, R.A. 1983b. A process model of internal corporate venturing in the diversified major firm. Administrative Science Quarterly 28: 223-244.

Burgelman, R.A. 1984. Designs for Corporate Entrepreneurship In Established Firms. California Management Review 6, 154-166.

Burgelman, R.A. 1991. Intraorganizational ecology of strategy making and organizational adaptation: theory and field research. Organization Science 2(3): 239-262.

Burgelman, R.A., Välikangas, L. 2005. Managing internal corporate venturing cycles. Sloan Management Review 46(4), 26-34.

Burns, T. en G. Stalker, (1961), The Management of Innovation, Tavistock, London. 
Christensen, C.M. (1997), The innovator's dilemma, Harvard Business School Press: Boston, MA.

Danneels, E. 2004. Disruptive technology reconsidered: a critique and research agenda. Journal of Product Innovation Management 21: 246-258.

Dierickx, I., Cool, K. 1989. Asset stock accumulation and sustainability of competitive advantage. Management Science 35, 1504-1511.

Duncan, R. B. 1976. The ambidextrous organization: designing dual structures for innovation, in R. H. Kilmann, L. R. Pondy and D. P. Slevin (eds.), The Management of Organization Design, 1: 167-188, New York: Elsevier North-Holland.

D’Aveni, R.A. 1994. Hypercompetition: Managing the Dynamics of Strategic Maneuvering. New York: The Free Press.

D'Aveni, R.A. 1999. Strategic supremacy through disruption and dominance. Sloan Management Review 40: 127-135.

Eisenhardt, K. M. \& J. A. Martin, (2000), 'Dynamic capabilities: what are they?', Strategic Management Journal 21, 1105-1121.

Fast, N. D. 1979. The rise and fall of corporate new venture divisions. Ann Arbor: V.M.I. Research Press.

Floyd, S.W., Lane, P.J. 2000. Strategizing throughout the organization: managing role conflict in strategic renewal. Academy of Management Review 25: 154-177.

Forte, M., Hoffman, J.J., Lamont, B.T., Brockmann, E.N. 2000. Organizational form and environment: an analysis of between-form and within-form responses to environmental change. Strategic Management Journal 21, 753-773.

Gibson, C.B., Birkinshaw, J. 2004. The antecedents, consequences and mediating role of organizational ambidexterity. Academy of Management Journal 47(2): 209-226.

Govindarajan, V., Kopalle, P.K. 2006. The usefulness of measuring disruptiveness of innovations ex post in making ex ante predictions. Journal of Product Innovation Management 23: 12-18.

Guth, W.D., Ginsberg, A. 1990. Guest editors' introduction: corporate entrepreneurship. Strategic Management Journal 11(special issue): 5-15.

Hamel, G., Heene, A. (eds) 1994. Competence-based Competition. Chicester: John Wiley.

Hill, C.W.L., Rothearmel, F.T. 2003. The performance of incumbent firms in the face of radical technological innovation. Academy of Management Review 28(2), 257-274.

Husted, K., Vintergaard, C. 2004. Stimulating innovation through corporate venture bases. Journal of World Business 39, 296-306.

Huff, J.O., Huff, A.S., Thomas, H. 1992. Strategic renewal and the interaction of cumulative stress and inertia. Strategic Management Journal 13(special issue): 55-75.

Jansen, J.J.P., Van den Bosch, F.A.J., Volberda, H.W. 2005. Managing potential and realized absorptive capacity: how do organizational antecedents matter? Academy of Management Journal 48(6), 999-1016. 
Kirzner IM. 1973. Competition and Entrepreneurship, University of Chicago Press: Chicago, IL.

Lumpkin, G.T., Dess, G.G. 2001. Linking two dimensions of entrepreneurial orientation to firm performance: the moderating role of environment and industry life cycle. Journal of Business Venturing 16: 429-451.

March, James G. 1991. Exploration and exploitation in organizational learning. Organization Science, 2 (1): 71-87.

McGrath, R.G. 2001. Exploratory learning, innovative capacity, and managerial oversight. Academy of Management Journal 44(1), 118-131.

Methe, D., Swaminathan, A., Mitchell, W., Toyama, R. 1997. The underemphasized role of diversifying entrants and industry incumbents as the sources of major innovations. In: Thomas, H., O’Neal, D. (Eds.), Strategic Discovery: Competing in New Arenas. New York: Wiley. 99-116.

Miller D. and P. Friesen 1982. Innovation in conservative and entrepreneurial firms: two models of strategic momentum. Strategic Management Journal 3: 1-25.

Naman. J.L., Slevin, D.P. 1993. Entrepreneurship and the concept of fit: a model and empirical tests. Strategic Management Journal 14, 137-153.

Penrose, E. (1959), The theory of the growth of the firm, Wiley, New York.

Prahalad, C. K. \& G. Hamel, (1990), 'The core competence of the corporation', Harvard Business Review 68 (May-June), 79-91.

Quinn, J.B. 1989. Pilkington Brothers Plc. In. Mintzberg, H., Quinn, J. B., Ghoshal, S. 1995. The Strategy Process. Hemel Hempstead: Prentice Hall.

Rebello, K. 1992. Microsoft: Bill Gates' baby is on top of the world. Can it stay there? Business Week February 24: 62-64.

Rumelt, R.P. 1994. Foreword. In: G. Hamel and A. Heene (eds). Competence-based Competition. Chicester: John Wiley, xv-xix.

Sanchez, R. 2001. Building blocks for strategy theory: resources, dynamic capabilities and competences. In: H.W. Volberda and T. Elfring (eds). Rethinking Strategy. London: Sage Publications 143-157.

Sanchez, R. 2004a. Understanding competence-based management: identifying five modes of competence. Journal of Business Research 57: 518-532.

Sanchez, R. 2004b. Creating modular platforms for strategic flexibility. Design Management Review (winter) 58-67.

Sanchez, R. and A. Heene 1997. Competence-based strategic management: concepts and issues for theory, research and practice. In: R. Sanchez and A. Heene (eds). Competence-based strategic management. Chicester: John Wiley \& Sons 3-42.

Sanchez, R. and A. Heene 2002. Managing strategic change: a systems view of strategic organizational change and strategic flexibility. In: J. Morecroft, R. Sanchez and A. Heene (eds). Systems perspectives on resources, capabilities, and management processes. Oxford: Elsevier Science 71-91. 
Sanchez, R., Heene, A. and H. Thomas 1996. Towards the theory and practice of competencebased competition. In: R. Sanchez, A. Heene and H. Thomas (eds). Dynamics of competence-based competition: theory and practice in the new strategic management. London: Elsevier, 1-35.

Sanchez, R., Mahoney, J.T. 1996. Modularity, flexibility, and knowledge management in production and organization design. Strategic Management Journal 17(special issue), 63-76.

Schumpeter, J.A. 1934. The Theory of Economic Development. Cambridge MA: Harvard University Press.

Sharma, P., Chrisman, J.J. 1999. Toward a reconciliation of the definitional issues in the field of corporate entrepreneurship. Entrepreneurship Theory and Practice 23(3): 11-27.

Sorrentino, M, Williams, M.L. 1995. Relatedness and corporate venturing: does it really matter? Journal of Business Venturing 10, 59-73.

Stopford, J.M., Baden-Fuller, C.W.F. 1994. Creating corporate entrepreneurship. Strategic Management Journal 15: 521-536.

Teece, D. J. and Pisano, G. and Shuen, A. (1997). 'Dynamic capabilities and strategic management’. Strategic Management Journal, 18, 509-533.

Thornhill, S., Amit, R. 2001. A dynamic perspective of internal fit in corporate venturing. Journal of Business Venturing, 16, 25-50.

Tosi, H., Aldag, R., Storey, R. 1973. On the measurement of the environment: An assessment of the Lawrence and Lorsch environmental uncertainty questionnaire. Administrative Science Quarterly 18: 27-36.

Tripsas, M. 1997. Unraveling the process of creative destruction: complementary assets and incumbent survival in the typesetter industry. Strategic Management Journal 15(Summer special issue): 119-142.

Tripsas, M., Gavetti, G. 2000. Capabilities, cognition and inertia: evidence from digital imaging, Strategic Management Journal 21: 1147-1161.

Tsai, W.M., MacMillan, I.C., Low, M.B. 1991. Effects of strategy and environment on corporate venture success in industrial markets. Journal of Business Venturing 6: 9-28.

Tushman, M.L., Anderson, P. 1986. Technological Discontinuities and Organizational Environments. Administrative Science Quarterly 31: 439-465.

Volberda, H.W. 1998. Building the Flexible Firm: How to remain competitive. London: Oxford University Press.

Volberda, H.W., Baden-Fuller, C., Van den Bosch, F.A.J., 2001. Mastering strategic renewal: Mobilising renewal journeys in multi-unit firms. Long Range Planning 34: 159-178.

Volberda, H.W., Lewin, A.Y. 2003. Co-evolutionary dynamics within and between firms: from evolution to co-evolution. Journal of Management Studies 40(8): 2105-2130.

Weick, K.E. 1979. The social psychology of organizing. Reading: Addison-Wesley.

Wernerfelt, B. (1984). 'A resource-based view of the firm'. Strategic Management Journal, 5, 171-180. 
Zahra, S.A. 1993. Environment, corporate entrepreneurship and financial performance: a taxonomic approach. Journal of Business Venturing 8: 319-340.

Zahra, S.A. 1996. Technology strategy and financial performance: examining the moderating role of the firm's competitive environment. Journal of Business Venturing 11: 189-219.

Zahra, S.A., Nielsen, A.P., and W.C. Bogner 1999. Corporate entrepreneurship, knowledge, and competence development. Entrepreneurship Theory and Practice 23: 169-189. 
FIGURE 2

Four generic types of environment: Contingencies and Competence Subprocesses

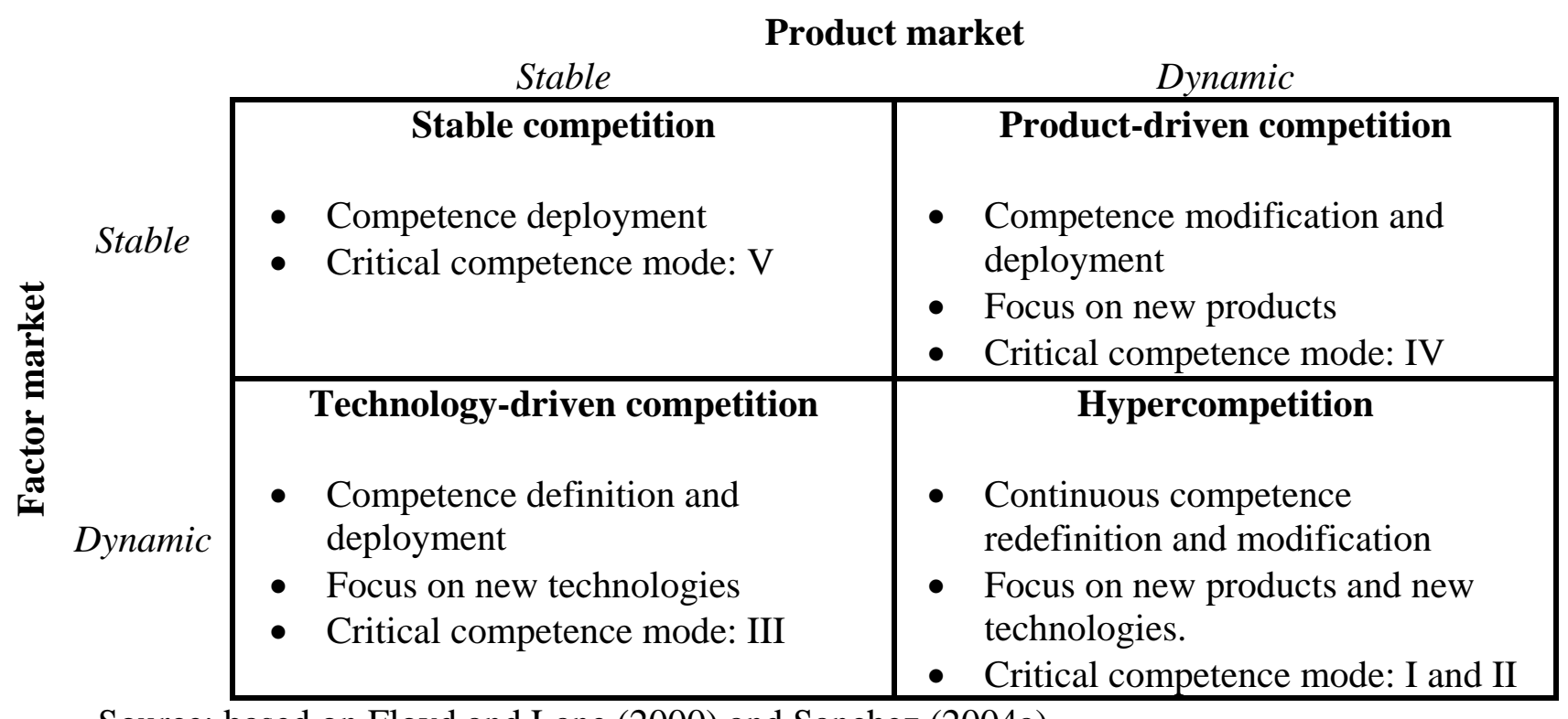

Source: based on Floyd and Lane (2000) and Sanchez (2004a) 
FIGURE 1

\section{Balanced competence modes and their flexibility mix}
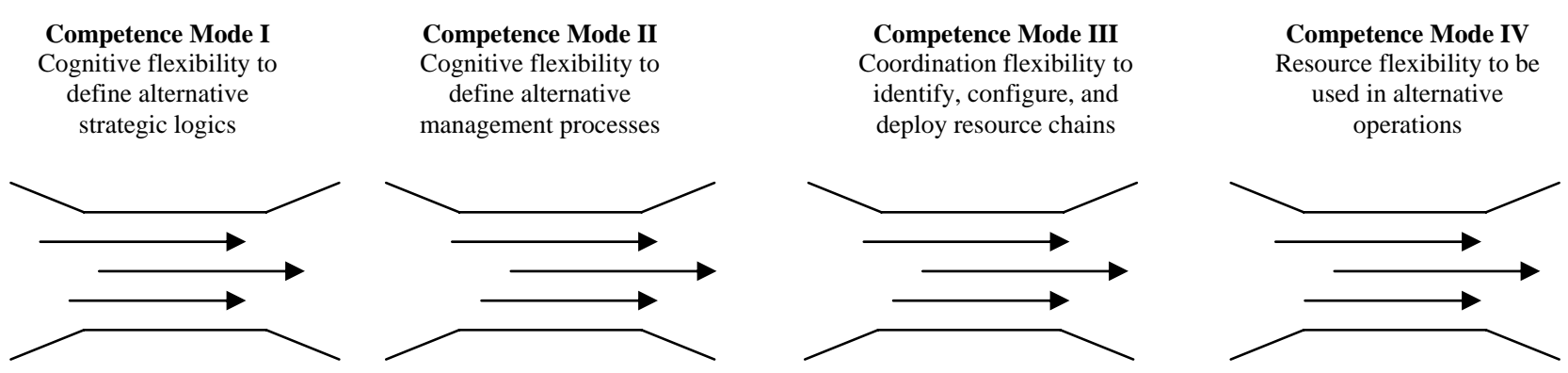

Competence Mode V

Operating flexibility in

using available resources

Source: based on Sanchez (2004a).

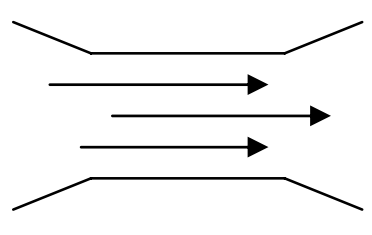




\section{FIGURE 3}

From stable to a dynamic product market: product development ventures increasing the level of flexibility in all five competence modes

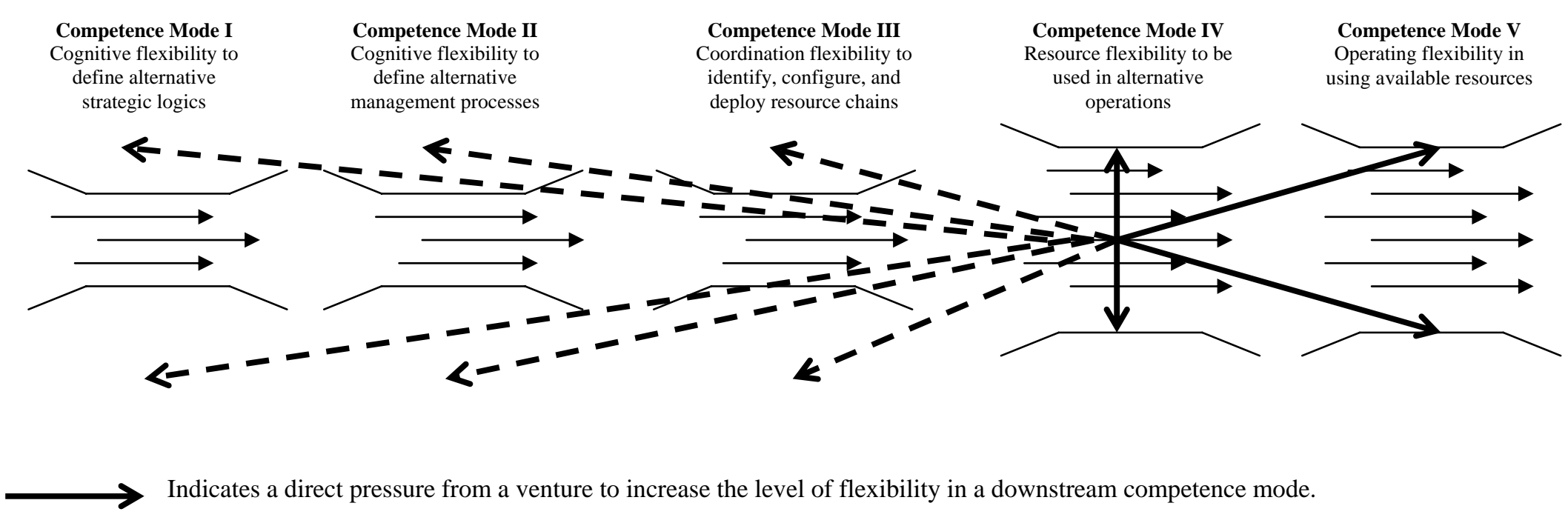
Indicates a indirect, lagged pressure from a venture to increase the level of flexilibility in an upstream competence mode to adapt to changed
environmental circumstances and to remove bottlenecks in the flexibility funnel. 


\section{FIGURE 4}

From stable to dynamic factor market: Technology development ventures increasing the level of flexibility in all five competence

\section{modes}

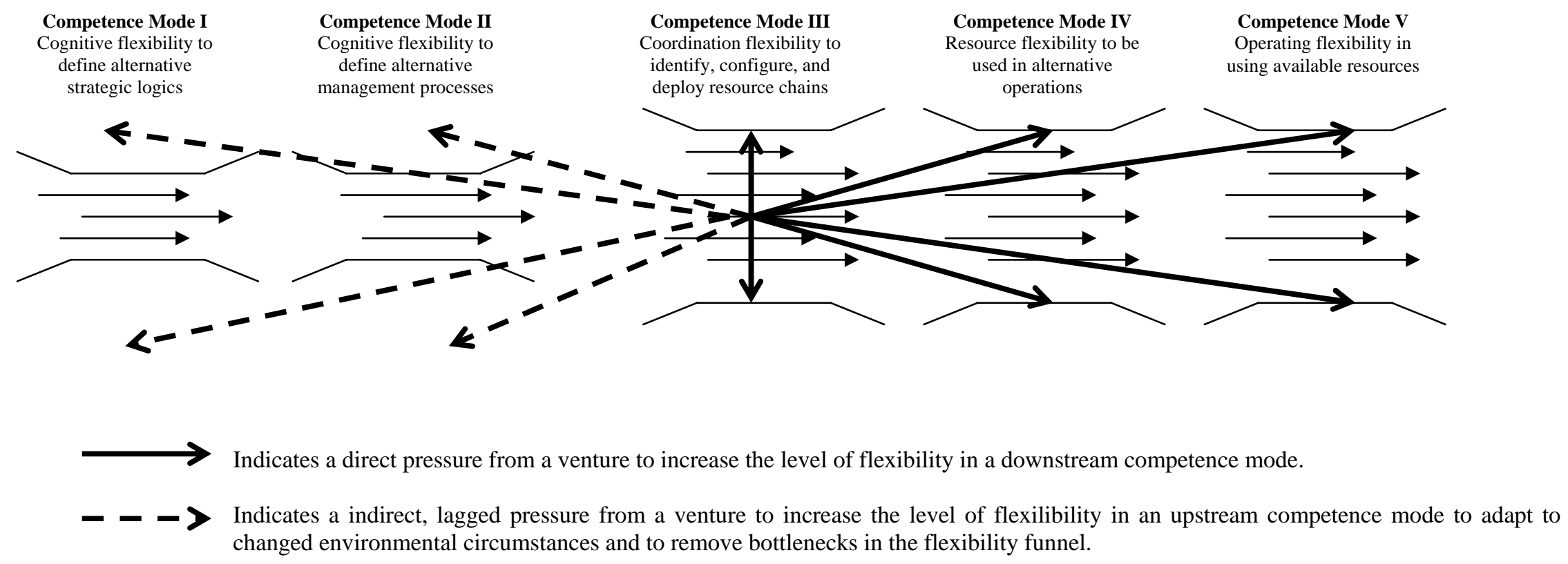




\section{Publications in the Report Series Research ${ }^{*}$ in Management}

\section{ERIM Research Program: "Strategy and Entrepreneurship"}

2007

Longitudinal Study on the Performance of U.S. Pharmaceutical Firms: The Increasing Role of Marketing

L.H. Pattikawa

ERS-2007-020-STR

http://hdl.handle.net/1765/9400

The Impact of Corporate Venturing on a Firm's Competence Modes J. Henri Burgers, Frans A.J. Van Den Bosch and Henk W. Volberda ERS-2007-061-STR

\footnotetext{
A complete overview of the ERIM Report Series Research in Management: https://ep.eur.nl/handle/1765/1

ERIM Research Programs:

LIS Business Processes, Logistics and Information Systems

ORG Organizing for Performance

MKT Marketing

F\&A Finance and Accounting

STR Strategy and Entrepreneurship
} 